This document is the accepted manuscript version of the following article:

Grob, N. M., Behe, M., von Guggenberg, E., Schibli, R., \& Mindt, T. L. (2017). Methoxinine - an alternative stable amino acid substitute for oxidationsensitive methionine in radiolabelled peptide conjugates. Journal of Peptide Science, 23(1), 38-44. https://doi.org/10.1002/psc.2948

\title{
Methoxinine - An Alternative Stable Amino Acid Substitute for Oxidation-Sensitive Methionine in Radiolabeled Peptide Conjugates
}

Nathalie M. Grob, ${ }^{1}$ Martin Behe,,${ }^{*}$ Elisabeth von Guggenberg, ${ }^{3}$ Roger Schibli, ${ }^{1,2}$ Thomas L. Mindt ${ }^{*}, 1,4$

1 Center for Radiopharmaceutical Sciences ETH-PSI-USZ, Institute of Pharmaceutical Sciences ETH, Vladimir-Prelog Weg 4, CH-8093 Zurich, Switzerland

${ }^{2}$ Center for Radiopharmaceutical Sciences ETH-PSI-USZ, Paul Scherrer Institute, CH-5232 Villigen, Switzerland

${ }^{3}$ Department of Nuclear Medicine, Medical University of Innsbruck, A-6020, Innsbruck, Austria

${ }^{4}$ Ludwig Boltzmann Institute Applied Diagnostics, General Hospital of Vienna, Währinger Gürtel 18-20, A-1090 Vienna, Austria

* Corresponding authors: E-mail: t.mindt@gmx.ch; Tel.: +41 4463374 92; martin.behe@psi.ch, Tel.: +415631028 17

$\dagger$ Electronic supplementary information (ESI) available: DOI ..... This material includes MS data and UV- and $\gamma$-HPLC chromatograms of peptide conjugates and the respective ${ }^{177} \mathrm{Lu}-$ labeled analogs.

\begin{abstract}
Radiolabeled peptides with high specificity and affinity towards receptors that are overexpressed by tumour cells are used in nuclear medicine for the diagnosis (imaging) and therapy of cancer. In some cases, the sequences of peptides under investigations contain methionine (Met), an amino acid prone to oxidation during radiolabeling procedures. The formation of oxidative side products can affect the purity of the final radiopharmaceutical product and/or impair its specificity and affinity towards the corresponding receptor. The replacement of Met with oxidation resistant amino acid analogs, e.g., norleucine (Nle), can provide a solution. While this approach has been applied successfully to different radiolabeled peptides, a Met $\rightarrow$ Nle switch only preserves the length of the amino acid side chain important for hydrophobic interactions but not its hydrogen-bonding properties. We report here the use of methoxinine (Mox), a non-canonical amino acid that resembles more closely the electronic properties of Met in comparison to Nle. Specifically, we replaced $\mathrm{Met}^{15}$ by Mox ${ }^{15}$ and Nle in the binding sequence of a radiometal-labeled minigastrin derivative (MG11). A comparison of the physicochemical properties of ${ }^{177}$ Lu-DOTA $\left[\mathbf{X}^{15}\right]$ MG11 ( $\mathbf{X}=$ Met, Nle, Mox $)$ in vitro (cell internalization/externalization properties, receptor affinity $\left(\mathrm{IC}_{50}\right)$, blood plasma stability,
\end{abstract}


and $\log \mathrm{P}$ ) showed that Mox indeed represents a suitable, oxidation-stable amino acid substitute of Met in radiolabeled peptide conjugates.

Keywords Minigastrin, CCK2 receptor, radiolabeled peptides, Lu-177, nonnatural amino acids, substitution of methionine

\section{ABBREVIATIONS}

AcN, Acetonitrile; BB, bombesin; BFCA, bifunctional chelating agent; BSA, bovine serum albumin; $\operatorname{CCK}(\mathrm{R})$, cholecystokinin (receptor); DIPEA, N,N-diisopropylethylamine; DMEM, Dulbecco's Modified Eagle Medium; DMF, $N, N$-dimethylformamide; DOTA, 1,4,7,10tetraazacyclododecane-1,4,7,10-tetraacetic acid; DOTA-tris(tBu)ester, 2-(4,7,10-tris(2-(tertbutoxy)-2-oxoethyl)-1,4,7,10-tetraazacyclododecan-1-yl)acetic acid; DTPA, diethylenetriaminepentaacetic acid; EDT, Ethane-1,2-dithiol; EDTA, ethylenediaminetetraacetic acid; EX, exendin; FCS, fetal calf serum; HATU, O-(7azabenzotriazol-1-yl)-N,N,N',N'-tetramethyluronium hexafluorophosphate; Hms, homoserine methyl ether; MBHA, 4-methylbenzhydrylamine; Met, Methionine; Met(se), Selenomethionine, MG, minigastrin; Mox, Methoxinine (O-methyl-L-homoserine); Nle, Norleucine; PBS, phosphate buffered saline (potassium free); rt, room temperature; SPECT, single-photon emission computed tomography; TFA, trifluoroacetic acid; TIS, triisopropylsilane

\section{INTRODUCTION}

Radiolabeled peptides with high specificity and affinity towards membrane-bound receptors that are overexpressed by tumour cells have become an indispensable tool in nuclear medicine for the diagnosis (imaging) and radioendotherapy of cancer.[1-2] As a result, the number of peptide vectors reported in preclinical and clinical investigations for the selective delivery of different radionuclides to tumours and metastases is steadily increasing.[3]

The development of targeted radiolabeled drugs (radiopharmaceuticals) includes the conjugation of a radionuclide to a vector molecule, e.g., peptides. For the radiolabeling of (bio)molecules with metallic radionuclides (e.g. ${ }^{111} \mathrm{In},{ }^{99 \mathrm{~m}} \mathrm{Tc},{ }^{68} \mathrm{Ga},{ }^{177} \mathrm{Lu}$ ), bifunctional chelating agents (BFCAs) are employed, which are typically low molecular weight molecules that enable both the stable complexation of the radiometal via an appropriate chelating system and its selective attachment to e.g., a tumor-targeting vector of interest. Preferably, the radiolabeling of a prodrug with a radionuclide is performed as the last step of the preparation of a radiopharmaceutical for reasons of time restrictions due to radioactive decay, logistics, and regulatory aspects. In the majority of cases, the radiolabeling step requires elevated temperatures and exposure of reagents and substrates to oxygen cannot be avoided. This in combination with the ionizing radiation employed can impair the quality of the final product because of the occurrence of radiolysis (cleavage of covalent bonds) and/or the formation of oxidized side products. The integrity of the final radiopharmaceutical product can often be sustained by addition of antioxidants/radical scavengers (e.g., ascorbic acid, gentisic acid, or methionine/selenomethionine)[4]; however, each component in the final formulation of a radiopharmaceutical requires additional quality control and toxicological evaluation for approval by regulatory authorities. Thus, the avoidance of the formation of side products by, 
e.g., substitution of moieties susceptible to oxidative side reactions, is of higher practicability than the use of additives.

Different radiolabeled peptides currently studied as molecular imaging probes or radioendotherapeutics in pre-clinical and clinical research contain the amino acid methionine (Met) including, e.g., derivatives of the tumour targeting sequences of bombesin (BB)[5], exendin (EX)[6], and minigastrin (MG)[7]. The methyl sulfide functional group in the side chain of Met is particularly prone to oxidation during radiolabeling reactions. Formation of sulfoxide by-products as the result of oxidative side reactions cannot only lead to a decrease of the radiochemical purity of the peptidic radiotracer but also result in a loss of specificity and affinity of the conjugate towards its corresponding receptors.[4, 8-9]

A common strategy to avoid potential issues in radiotracer development arising from peptidic vectors containing a Met residue is the substitution of the amino acid with other stable, canonical or non-canonical analogs. In this context, norleucine (Nle; Figure 1) has been successfully employed as a non-oxidizable substitute of Met in, e.g., radiolabeled derivatives of $\mathrm{BB}[10]$, EX[11], and MG[9, 12-13]. In these examples, the Met $\rightarrow$ Nle substitution led to peptide analogs with preserved biological activity that are stable during radiolabeling reactions. The replacement of the sulphur atom in Met by the methylene group of Nle approximately maintains the length of the amino acid side chain important for hydrophobic interactions; however, it does not preserve the original hydrogen bonding acceptor properties. Surprisingly little attention has been paid in the radiopharmaceutical literature to potential substitutes of Met other than Nle even though alternatives exist. For example, homoserin methylether (Hms), also termed methoxinine (Mox), is a structurally similar but electronically more closely related amino acid substitute of Met than the currently used Nle (Figure 1). While a Met $\rightarrow$ Mox switch has been reported in the peptide and protein literature for, e.g., studying protein folding, [14-19] application of Mox as an alternative, oxidation-stable substitute for Met in radiopharmaceutical development has, to the best of our knowledge, not yet been studied systematically.

We have recently started to investigate the utility of Mox to replace Met in peptide conjugates in order to increase the stability of the peptide during radiolabeling reactions. In a first study, we were able to show that ${ }^{177} \mathrm{Lu}$-DOTA-labeled derivatives of the tumour-targeting peptide bombesin, namely ${ }^{177} \mathrm{Lu}-\mathrm{DOTA}-\mathrm{PEG}_{4}-\left[\mathrm{Mox}^{14}\right] \mathrm{BB}(6-14)$ and the corresponding $\mathrm{BB}(7-14)$ analogue, exhibited superior in vitro properties and in vivo tumour-targeting performances in comparison to the corresponding $\left[\mathrm{Met}^{14}\right]$ - and $\left[\mathrm{Nle}^{14}\right]-\mathrm{BB}$ analogs.[10] We now wish to report the second example of a side-by-side comparison of the effect of the substitution of Met by Nle and Mox exemplified with radiometallated MG derivatives.

MG is a truncated analogue of gastrin, an endogenous peptide closely related to the cholecystokinins (CCK).[20-22] The molecular target of both peptides are the cholecystokinin receptors (CCKR) of which the subtype CCK2R is found overexpressed in high incidence by different tumour cells including those of medullary thyroid, small cell lung, and stromal ovarian cancers.[23] In the past years, a number of radiolabeled derivatives of gastrins and CCKs have been investigated as diagnostic imaging probes or radioendotherapeutics in nuclear oncology among which analogs of MG (e.g., MG11 without the N-terminal poly-Glu motif of MG; Figure1) exhibited interesting properties for clinical translation.[7, 24-26] The substitution of Met by Nle or other amino acids in position 15 of the sequence of MG11 has been described.[12-13, 27-28] Also, the employment of Mox in non-radiolabeled analogs of 
little gastrin and CCK analogs was reported some years ago, however, with varying results.[14-15] We report here the first successful application of Mox as a substitute of Met in a radiolabeled MG11 analogue.

\section{MATERIAL AND METHODS}

\section{General Methods}

Reagents were purchased from Sigma Aldrich (St. Louis, MO, USA), Thermo Fisher Scientific (Waltham, MA, USA), Acros Chemicals (New Jersey, USA), TCI (Tokyo, Japan), Fluka (Buchs, Switzerland), Merck (Darmstadt, Germany), AppliChem (Darmstadt, Germany), BioConcept (Allschwil, Switzerland), VWR (Radnor, PA, USA), or Avantor Performance (Center Valley, PA, USA) and used without further purification. Fmoc-protected amino acids and rink amide MBHA LL resin (0.30-0.40 mmol/g, 100-200 mesh) were bought from NovaBiotech (Darmstadt, Germany) or Bachem (Bubendorf, Switzerland). Fmoc-Mox$\mathrm{OH}$ was purchased from Iris Biotech (Marktredwitz, Germany) and DOTA-tris( $t$ Bu)ester from CheMatech (Dijon, France). Non-carrier-added ${ }^{177} \mathrm{LuCl}_{3}$ was purchased from ITG (Garching, Germany). Human blood was collected in heparinized syringes (S-Monovette $\mathbb{R}$ $5.5 \mathrm{~mL} \mathrm{LH}$, Sarstedt, Nürbrecht, Germany) and centrifuged (5 min, $3000 \mathrm{rpm}$, RT) to separate the plasma. Minigastrin (LEEEEEAYGWMDF-NH $\mathrm{H}_{2}$ ) for blocking experiments and reference DOTA-PP-F11N (DOTA-(DGlu) ${ }_{6}$-Ala-Tyr-Gly-Trp-Nle-Asp-Phe-NH ${ }_{2}$ )[29], were purchased from Peptide Speciality Laboratories GmbH (Heidelberg, Germany).

UV-Measurements for standard solid phase peptide synthesis (SPPS) were conducted on an Agilent Technologies Cary $60 \mathrm{UV}-\mathrm{Vis}$ spectrophotometer. The scale and yield of the SPPS were determined by quantification of the fluerenylmethylpiperidine adduct at $\lambda=301 \mathrm{~nm}(\varepsilon=$ $\left.7800 \mathrm{~L} \cdot \mathrm{mol}^{-1} \mathrm{~cm}^{-1}\right)$. Measurements of UV-absorption at $\lambda=280 \mathrm{~nm}$ on an IMPLEN NanoPhotometer P360 were used to determine the concentrations of peptide conjugate stock solutions $\left(\varepsilon=6990 \mathrm{~L} \cdot \mathrm{mol}^{-1} \mathrm{~cm}^{-1}\right.$; calculated for EAYGWXDF by ExPASy - ProtParam of the Swiss Institute of Bioinformatics, $\mathrm{X}^{15}=$ Met, Nle, Mox).

HPLC was performed on a Merck Hitachi LaChrom D-7000 HPLC-system monitored by UVdetection at $215 \mathrm{~nm}$ and additionally by a Berthold HPLC Radioactivity monitor LB $506 \mathrm{C}-1$ for $\gamma$-HPLC. Plasma stability assays by HPLC were conducted on a Dionex Ultimate 3000 HPLC-system with UV-detection at $280 \mathrm{~nm}$ and a Raytest Gabi STAR HPLC radioactivity monitor. Columns and gradients used for each purpose can be found in the Supporting Information.

HRMS were recorded on a Bruker maXis (UHR-TOF) with ESI ion source and Qq-TOF analyser in positive mode and processed by the software Compass 1.5, HyStar 3.2.44, DataAnalysis 4.1 and BioTools 3.3.

(Radio-)Metal-labeling was conducted in $1.5 \mathrm{~mL}$ protein low-binding Eppendorf tubes. An Eppendorf Thermomixer comfort (Eppendorf, Hamburg, Germany) was used for heating and simultaneous shaking of the labeling mixture.

Quantitative $\gamma$-counting was performed by a Packard COBRA-II Auto-Gamma counter (Perkin Elmer, Waltham, MA, USA) by measuring energy windows A (50-400 keV) and B (190-230 keV) for $1 \mathrm{~min}$. 


\section{Peptide Synthesis}

The rink amide MBHA LL resin (ca. $150 \mathrm{mg}, 0.05 \mathrm{mmol}$ ) was placed in a polypropylene syringe with a polyethylene frit and a teflon tap and swollen repeatedly in $\mathrm{CH}_{2} \mathrm{Cl}_{2}$ and DMF. $20 \%$ piperidine in DMF was used to cleave the Fmoc protecting group $(3 \times 3 \mathrm{~min}, \mathrm{rt})$. For elongation of the sequence, the Fmoc-protected amino acids or DOTA-(tris- $t \mathrm{Bu})$ ester (2 equiv., $0.1 \mathrm{mmol}$ ), HATU (1.9 equiv., $0.095 \mathrm{mmol}$ ) and DIPEA (5 equiv., $0.25 \mathrm{mmol}$ ) in DMF (total $5 \mathrm{~mL}$ ) were added to the resin. The suspension was shaken for $1.5 \mathrm{~h}$ at $\mathrm{rt}$. The solvent was removed by filtration, and the resin was repeatedly washed with DMF and $\mathrm{CH}_{2} \mathrm{Cl}_{2}$. Completion of the reaction was monitored by the Kaiser test[30] and repeated if necessary.

After the final coupling of the $\mathrm{N}$-terminal chelator $(t \mathrm{Bu})_{3} \mathrm{DOTA}$, the conjugates were deprotected and cleaved from the resin using either cocktail A $\left(6 \mathrm{~mL}\right.$; TFA/TIS $/ \mathrm{H}_{2} \mathrm{O} /$ phenol; $92.5 / 2.5 / 2.5 / 2.5)$ or B (6 mL; TFA/TIS/ $\mathrm{H}_{2} \mathrm{O} /$ thioanisole/EDT; $\left.90 / 2.5 / 2.5 / 2.5 / 2.5\right)$ with agitation for $5 \mathrm{~h}$ at $\mathrm{rt}$. The cleavage mixture was separated from the resin by filtration and a stream of nitrogen was applied for evaporation of the volatile components. The crude peptide was then precipitated by the addition of ice-cold diethyl ether $(15 \mathrm{~mL})$. After centrifugation (1800 rpm, $5 \mathrm{~min}$ ) and two washing steps with ice-cold diethyl ether, the crude peptide conjugates were dissolved in $20 \% \mathrm{CH}_{3} \mathrm{CN}$ in water $(1 \mathrm{mg} / \mathrm{mL})$ and purified by reverse phase semipreparative HPLC (for HPLC conditions see the Supporting Information). Subsequent lyophilisation gave the final products as white powders. For yields, purity and MS data see Table 1 and the Supporting Information.

DOTA[Met ${ }^{15}$ ]MG11 was prepared following the general procedures as outlined above using DOTA-(tris- $t \mathrm{Bu})$ ester, Fmoc-DGlu( $(\mathrm{O} t \mathrm{Bu})-\mathrm{OH}$, Fmoc-Ala-OH, Fmoc-Tyr $(t \mathrm{Bu})-\mathrm{OH}$, FmocGly-OH, Fmoc-Trp(Boc)-OH, Fmoc-Met-OH, Fmoc-Asp $(\mathrm{O} t \mathrm{Bu})-\mathrm{OH}$, and Fmoc-Phe-OH. Degassed DMF was used for all reactions and washing steps to reduce the oxidation rate of the thioether. Cocktail B was used for the cleavage of DOTA[Met $\left.{ }^{15}\right] \mathrm{MG} 11$ from the resin.

DOTA[Nle ${ }^{15}$ ]MG11 was prepared following the general procedures as outlined above using DOTA-(tris- $t \mathrm{Bu})$ ester, Fmoc-DGlu( $(\mathrm{O} t \mathrm{Bu})-\mathrm{OH}$, Fmoc-Ala-OH, Fmoc-Tyr $(t \mathrm{Bu})-\mathrm{OH}$, FmocGly-OH, Fmoc-Trp(Boc)-OH, Fmoc-Nle-OH, Fmoc-Asp(OtBu)-OH, and Fmoc-Phe-OH. Cocktail A was used for the cleavage of DOTA[Nle $\left.{ }^{15}\right] \mathrm{MG} 11$ from the resin.

DOTA[Mox ${ }^{15}$ ]MG11 was prepared following the general procedures as outlined above using DOTA-(tris- $t \mathrm{Bu})$ ester, Fmoc-DGlu(OtBu)-OH, Fmoc-Ala-OH, Fmoc-Tyr $(t \mathrm{Bu})-\mathrm{OH}$, FmocGly-OH, Fmoc-Trp(Boc)-OH, Fmoc-Mox-OH, Fmoc-Asp(OtBu)-OH, and Fmoc-Phe-OH. Cocktail A was used for the cleavage of DOTA[Mox $\left.{ }^{15}\right] \mathrm{MG11}$ from the resin.

\section{(Radio)metal Labeling}

Stock solutions were prepared by dissolving the peptide conjugates $(1 \mathrm{mg}, 750 \mathrm{nmol})$ in ammonium acetate buffer $(50 \mu \mathrm{L}, 0.5 \mathrm{M}, \mathrm{pH} 5.5)$ and addition of water to a final peptide concentration of $250 \mu \mathrm{M}$ (approx. $0.3 \mathrm{mg} / \mathrm{mL}$ ). DOTA-functionalized peptides ( $1 \mathrm{nmol}, 3.85$ $\mu \mathrm{L}$ of $250 \mu \mathrm{M}$ stock solution) were added to a mixture of aq. $\mathrm{HCl}(22.5 \mu \mathrm{L}, 0.05 \mathrm{M}, \mathrm{pH} 1.3)$ and ammonium acetate buffer $\left(15 \mu \mathrm{L}, 0.5 \mathrm{M}, \mathrm{pH}\right.$ 5.5). DOTA[Nle $\left.{ }^{15}\right] \mathrm{MG1} 1$ and DOTA[Mox $\left.{ }^{15}\right]$ MG11 were radiolabeled efficiently with or without addition of additives 
(sodium ascorbate; $0.83 \mu \mathrm{L}, 3 \mathrm{M}$ ), whereas in the case of DOTA[Met $\left.{ }^{15}\right] \mathrm{MG} 11$ the presence of antioxidants in the reaction mixtures (Met $(\mathrm{Se}) ; 5 \mu \mathrm{L}, 10 \mathrm{mM}$ ) was required to achieve high radiochemical purity of the product. The volume of ammonium acetate buffer was corrected according to the volume of added solutions of antioxidants. $20-25 \mathrm{MBq}$ of ${ }^{177} \mathrm{LuCl}_{3}$ (ca. 2.5 $\mu \mathrm{L}$, in $0.04 \mathrm{M} \mathrm{HCl}, 20-25 \mathrm{MBq} / \mathrm{nmol}$ ) were added and the mixtures were heated to $75^{\circ} \mathrm{C}$ for $30 \mathrm{~min}$ in a heating block. After labeling, a $2 \mu \mathrm{L}$ aliquot of the labeling mixture was added to aq. DTPA $(200 \mu \mathrm{L}, 25 \mu \mathrm{M})$ for quality control by $\gamma$-HPLC.

The reference substance for the $\mathrm{IC}_{50}$ assays DOTA-PP-F11-N was radiolabeled with ${ }^{177} \mathrm{Lu}$ analogously to the procedure described for DOTA[Nle $\left.{ }^{15}\right] \mathrm{MG} 11$ and DOTA[Mox $\left.{ }^{15}\right] \mathrm{MG} 11$. For the labeling with non-radioactive ${ }^{175} \mathrm{Lu}$, the test compounds $(25 \mathrm{nmol}, 100 \mu \mathrm{L}, 250 \mu \mathrm{M})$ were mixed with a 5-molar excess of aq. ${ }^{175} \mathrm{LuCl}_{3}(125 \mathrm{nmol}, 12.5 \mu \mathrm{L}, 10 \mathrm{mM})$, ammonium acetate $(5 \mu \mathrm{L}, 0.5 \mathrm{M}, \mathrm{pH} 5.5)$ and heated to $75{ }^{\circ} \mathrm{C}$ for $30 \mathrm{~min}$ in a heating block. DOTA[Met $\left.{ }^{15}\right] \mathrm{MG} 11$ was labeled with ${ }^{175} \mathrm{LuCl}_{3}$ in the presence of a 10 -molar excess of aq. $\operatorname{Met}(\mathrm{Se})(25 \mu \mathrm{L}, 10 \mathrm{mM})$.

\section{Cell Culture}

Human Medullary Thyroid Cancer cells (MZ-CRC1) expressing the CCK2R were grown in monolayers in Nunclon ${ }^{\mathrm{TM}}$ Delta treated cell culture flasks in humidified air at $5 \% \mathrm{CO}_{2}$ and 37 ${ }^{\circ} \mathrm{C}$. The cells were maintained in the culture medium DMEM (high glucose $(4.5 \mathrm{~g} / \mathrm{L})$ ) supplemented with $20 \mathrm{mM}$ L-Glutamine (L-Glu) and 10\% FCS. The culture was passaged regularly at 80 to $90 \%$ confluency using a $0.25 \%$ trypsin $0.38 \%$ EDTA solution. Assays were conducted in the assay medium DMEM (high glucose) containing $0.1 \%$ BSA.

\section{Cell Internalization Experiments}

On the day prior to the experiment MZ-CRC1 cells were placed in six-well plates $\left(0.85 \cdot 10^{6}\right.$ cells/well) in cell culture medium and incubated overnight for attachment. On the day of the experiment, the medium was removed and the cells were washed twice with $1 \mathrm{~mL}$ PBS. The plates were put on ice for preparation. $0.9 \mathrm{~mL}$ of assay medium was dispensed to all wells except the ones for nonspecific binding. 0.2 pmol of ${ }^{177} \mathrm{Lu}$ labeled conjugates $(100 \mu \mathrm{L}, 2 \mathrm{nM}$ in assay medium, ca. $4.2 \mathrm{kBq}$ ) were dispensed to all wells. For the determination of nonspecific binding, a 5000-fold excess of minigastrin ( $1 \mathrm{nmol}, 100 \mu \mathrm{L}, 10 \mu \mathrm{M}$ in assay medium) was added to $0.8 \mathrm{~mL}$ of assay medium containing the ${ }^{177} \mathrm{Lu}$ labeled conjugates. The plates were incubated at $37{ }^{\circ} \mathrm{C}$ in $5 \% \mathrm{CO}_{2}$ to allow binding and internalization. The process was stopped after 30 and $240 \mathrm{~min}$ by collection of the supernatant. The cells were washed twice with PBS (each $0.6 \mathrm{~mL}$ ). The combined supernatants represent the free, unbound fraction of radioactivity. Membrane-bound activity was determined by incubating the cells with cold saline glycine buffer $(0.6 \mathrm{~mL}, 0.05 \mathrm{M}, \mathrm{pH} 2.8)$ twice for $5 \mathrm{~min}$ at $\mathrm{rt}$. The internalized fraction was isolated by two cycles of cell lysis with $\mathrm{NaOH}$ (each $0.6 \mathrm{~mL}, 1 \mathrm{M}$, $10 \mathrm{~min}, \mathrm{rt}$ ). The radioactivity of the fractions was measured by a COBRA-II gamma counter and is represented as percentage of total applied radioactivity dosage ( $n=3-4$ in triplicates).

\section{Cell Externalization Experiments}

The plates were prepared as described in the procedure of cell internalization experiements. The internalization process was stopped after $120 \mathrm{~min}$, membrane-bound and internalized fractions were measured on a reference plate as described above. On the remaining plates, the 
supernatant was removed and discarded and the cells were washed twice with cold saline glycine buffer (each $0.6 \mathrm{~mL}, 0.05 \mathrm{M}, \mathrm{pH} 2.8,5 \mathrm{~min}, \mathrm{rt}$ ). Fresh assay medium $(1 \mathrm{~mL})$ was subsequently added to the wells and the plates were incubated further $\left(37^{\circ} \mathrm{C}, 5 \% \mathrm{CO}_{2}\right)$. After 15, $30 \mathrm{~min}, 1,2$ and $4 \mathrm{~h}$, the externalization experiment was stopped and the remaining intracellular fraction of radioactivity was determined by cell lysis according to the procedure described above for the cell internalization experiments ( $\mathrm{n}=1-2$ in triplicates).

\section{Receptor Affinity - IC $_{50}$ Assays}

On the day prior to the experiment MZ-CRC1 cells were placed in six-well plates $\left(0.85 \cdot 10^{6}\right.$ cells/well) in cell culture medium and incubated overnight for attachment. On the day of the experiment, the medium was removed and the cells were washed twice with $1 \mathrm{~mL}$ PBS. On ice, $0.8 \mathrm{~mL}$ of assay medium and the radiolabeled reference compound ${ }^{177}$ Lu-DOTA-PPF11N (0.2 pmol, $2 \mathrm{nM}$ in assay medium, $100 \mu \mathrm{L}$, ca. $4.2 \mathrm{kBq}$ ) were dispensed to each well (final concentration in well $=0.2 \mathrm{nM}$ ). ${ }^{175} \mathrm{Lu}$-labeled test compounds were added to reach final concentrations of $10^{-11}$ to $5 \cdot 10^{-6} \mathrm{M}$ /well $\left(100 \mu \mathrm{L}\right.$ of dilution series from $10^{-10}$ to $5 \cdot 10^{-5} \mathrm{M}$ in assay medium). Total binding of ${ }^{177} \mathrm{Lu}$-DOTA-PP-F1 $1 \mathrm{~N}$ was identified by incubation of the cells without addition of test compounds. After incubation of the plates at $4{ }^{\circ} \mathrm{C}$ for $1 \mathrm{~h}$, the supernatant was removed and cells were washed twice with $1 \mathrm{~mL}$ cold $\mathrm{PBS}$. $\mathrm{NaOH}$ was added twice to all wells for cell lysis $(0.6 \mathrm{~mL}, 1 \mathrm{M}, 10 \mathrm{~min}, \mathrm{rt})$. The radioactivity associated with the lysed cells was determined by a COBRA-II gamma counter. $50 \%$ inhibitory concentrations $\left(\mathrm{IC}_{50}\right)$ were calculated by normalized nonlinear regression with GraphPad Prism $(\mathrm{n}=3$ in triplicates)[29].

\section{Blood Plasma Stability}

The ${ }^{177}$ Lu-labeled peptide conjugates were diluted with $0.9 \% \mathrm{NaCl}$ to a concentration of 3.75 $\mu \mathrm{M}$ and incubated (375 pmol, $100 \mu \mathrm{L}, 7.5-12 \mathrm{MBq}$ ) in argon-flushed fresh human blood plasma $(1.5 \mathrm{~mL})$ at $37{ }^{\circ} \mathrm{C}$. At different time points $(0.5,1,2,4,6$ and $24 \mathrm{~h})$ aliquots $(75 \mu \mathrm{L})$ were taken and the proteins were precipitated in $\mathrm{CH}_{3} \mathrm{CN}(100 \mu \mathrm{L})$ and centrifuged $(2 \mathrm{~min}$, $14680 \mathrm{rpm}, \mathrm{rt})$. The supernatant $(75 \mu \mathrm{L})$ was diluted with water $(75 \mu \mathrm{L})$ and analyzed by $\gamma$ HPLC. One phase decay nonlinear regression $\left(A=A_{0} * e^{-k t}\right)$ was used to calculate the halflifes $\left(t_{1 / 2}\right)$ of the peptide conjugates with GraphPad Prism $(n=2-3)$.

\section{LogD Determination}

The lipophilicity of the radiolabeled peptide conjugates $(\log D)$ was determined by the "shake flask method". The radiolabeled conjugates (10 pmol, $10 \mu \mathrm{L}, 1 \mu \mathrm{M}$ in PBS, ca. $0.25 \mathrm{MBq})$ were added to a saturated 1:1 mixture of $n$-octanol/PBS (1 mL, pH 7.4) and shaken vigorously by vortex for $1 \mathrm{~min}$. After centrifugation (3000 rpm, $10 \mathrm{~min}$ ), $100 \mu \mathrm{L}$ aliquots of both phases were taken and the radioactivity was measured in a gamma counter $(\mathrm{n}=3)$.

\section{RESULTS AND DISCUSSION}

MG11 analogs functionalized N-terminally with a DOTA chelator were prepared by SPPS employing Fmoc/tBu chemistry (Figure 1). The peptide conjugates were obtained in good 
yields and high purity after HPLC purification and lyophilisation. Their structures were confirmed by mass spectrometric analysis (Table 1 ).

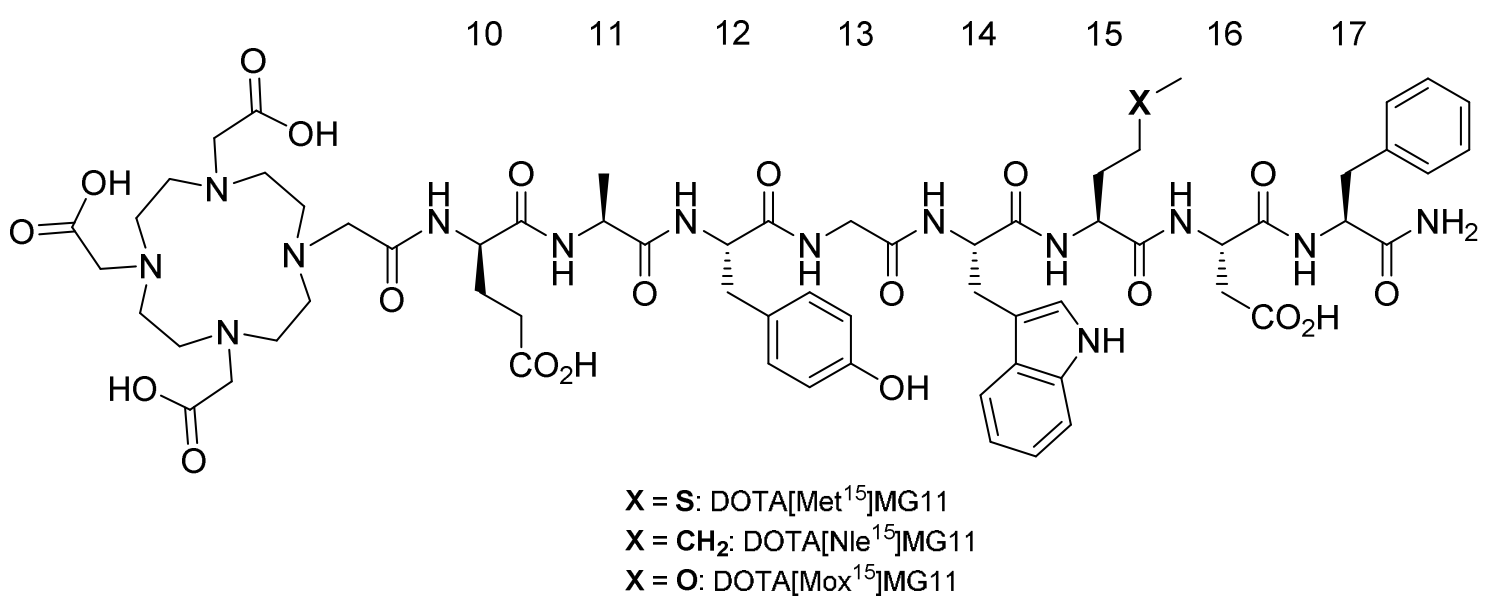

Figure 1. Structures of investigated DOTA-MG11 derivatives with numbering of the amino acid residues.

\section{[TABLE 1]}

The MG11 derivatives were conjugated to 1,4,7,10-tetraazacylododecane-1,4,7,10-tetraacetic acid (DOTA) because this universal macrocyclic chelator allows for the radiolabeling with different metallic radionuclides. In this study, we employed the radionuclide ${ }^{177} \mathrm{Lu}$ which is a therapeutic $\beta$-particle emitter with a concomitant $\gamma$-radiation for imaging by Single Photon Emission Computed Tomography (SPECT). DOTA-functionalized MG11 analogs were radiolabeled with no carrier added (n.c.a.) ${ }^{177} \mathrm{LuCl}_{3}$ according to established procedures in $\mathrm{NH}_{4} \mathrm{OAc}(0.5 \mathrm{M}, \mathrm{pH} 5.5)$ at $75{ }^{\circ} \mathrm{C}$ for 30 min yielding the corresponding radiolabeled conjugates ${ }^{177}$ Lu-DOTA[ $\left.\mathbf{X}^{15}\right]$ MG11 ( $\mathbf{X}=$ Met, Nle, Mox) with a specific activity of $19-25$ $\mathrm{MBq} / \mathrm{nmol}$ (not optimized) and in radiochemical yields and purities exceeding $>95 \%$ (see Supporting Information).[31-32] As expected, radiolabeling of DOTA[Nle $\left.{ }^{15}\right] \mathrm{MG} 11$ and DOTA[Mox $\left.{ }^{15}\right]$ MG11 did not lead to any formation of by-products. On the other hand, for DOTA[Met $\left.{ }^{15}\right] \mathrm{MG} 11$ addition of selenomethionine (Met(Se), ca $\left.1 \mathrm{mM}\right)$ to the radiolabeling reaction mixture was required to reduce the formation of sulfoxide by-product from approx. $20 \%$ to $<1 \%$ (see Supporting Information). For $\mathrm{IC}_{50}$ assays, the peptide conjugates were labeled with excess of non-radioactive ${ }^{175} \mathrm{LuCl}_{3}\left({ }^{\text {nat }} \mathrm{LuCl}_{3}\right)$ by analogous procedures. The products obtained were used for the in vitro assays without further purification.

The cell internalization and externalization properties of ${ }^{177}$ Lu-DOTA $\left[\mathbf{X}^{15}\right]$ MG11 $(\mathbf{X}=$ Met, Nle, Mox) were evaluated in vitro using human medullary thyroid cancer cells (MZ-CRC1) expressing the CCK2R (Figures 2 and 3). Receptor specificity of cell binding and uptake was verified by blocking experiments; in all cases the presence of excess Minigastrin (LEEEEEAYGWMDF- $\mathrm{NH}_{2}$ ) resulted in a decrease of cell associated radioactivity to $<2 \%$ (Figure 1 and Supporting Information). The affinities of conjugates towards CCK2R ( $\left.\mathrm{IC}_{50}\right)$ were determined by receptor binding competition experiments in which increasing concentrations of non-radioactive ${ }^{175} \mathrm{Lu}$-labeled conjugates were used to replace reference compound ${ }^{177}$ Lu-DOTA-PP-F11N $\left(\mathrm{IC}_{50}=8.5 \pm 2.6 \mathrm{nM}\right)[29]$. The hydrophilicities of radiolabeled compounds ( $\log \mathrm{D}$ values) were assessed by the shake flask method. Stability 
studies were conducted by incubation of the radioactive compounds in fresh human blood plasma and analysis of samples at different time points by $\gamma$-HPLC after precipitation of blood proteins (Figure 4). The physicochemical properties of metal labeled peptide conjugates Lu$\operatorname{DOTA}\left[\mathbf{X}^{15}\right]$ MG11 $\left(\mathbf{X}=\right.$ Met, Nle, Mox; $\left.\mathrm{Lu}={ }^{177 / \mathrm{nat}} \mathrm{Lu}\right)$ are summarized in Table 2.

Receptor specific cell internalization of ${ }^{177}$ Lu-DOTA $\left[\mathbf{X}^{15}\right]$ MG11 (X $=$ Met, Nle, Mox) in vitro was found to be in the same range reaching approx. $25-30 \%$ of applied dose after $4 \mathrm{~h}$ of incubation (Figure 1, Table 2). The cell membrane-bound fractions were below 3\% for all time points (Supporting Information). Also, the cell externalization of radioactivity was similar for the three radiolabeled peptide conjugates resulting in a retained intracellular fraction of approx. 50-60\% after $4 \mathrm{~h}$ (Table 2, Supporting Information). Receptor affinities $\left(\mathrm{IC}_{50}\right)$ of the metallated peptide conjugates as determined by receptor binding competition experiments were in the low two-digit nanomolar range for all three compounds, which is in agreement with data published on related, radiolabeled DOTA-functionalized MG11 derivatives (Figure 3, Table 2).[7, 9, 12] LogD values of the ${ }^{177}$ Lu-labeled MG11 conjugates were comparable (Table 2) independent on the amino acid residue in position 15 of the sequence. This indicates that the hydrophilicity of the conjugates was not significantly influenced by the structural modifications even though Mox has been described to be more hydrophilic than Met and Nle.[16] The incubation of the peptide conjugates in blood plasma lead to radiometabolites with increased hydrophilicity for all compounds tested. The calculated half-lifes were in the range of 1.7-2.4 h (Table 2). Interestingly, the blood plasma stability of ${ }^{177} \mathrm{Lu}$-DOTA[Met $\left.{ }^{15}\right] \mathrm{MG11}$ was slightly higher in comparison to the other two analogs tested, an observation which is in agreement with our previously published results on the binding sequence of the peptide bombesin[10]. In summary, our investigations of ${ }^{177} \mathrm{Lu}-$ DOTA $\left[\mathbf{X}^{15}\right]$ MG11 $(\mathbf{X}=$ Met, Nle, Mox $)$ revealed that the amino acid exchange in position 15 of the tumor targeting peptide MG11 did not significantly alter the in vitro physicochemical properties of the radiolabeled peptides but facilitated the radiolabeling procedure by avoiding the otherwise necessary addition of antioxidants.

\section{[TABLE 2]}

\section{[FIGURE 2]}

Figure 2. Internalization of ${ }^{177} \mathrm{Lu}$-radiolabeled peptide conjugates into MZ-CRC1 cells. Blocking experiments were performed in the presence of 5000-fold molar excess of Minigastrin; results are given as mean values \pm standard deviations $(n=3-4$ in triplicates); detailed information can be found in the Supporting Information.

\section{[FIGURE 3]}

Figure 3. Receptor bound fraction of reference compound ${ }^{177}$ Lu-DOTA-PP-F11N [[29]]with increasing concentrations of ${ }^{175} \mathrm{Lu}-\mathrm{DOTA}\left[\mathrm{Met}{ }^{15}\right] \mathrm{MG} 11(\bullet),{ }^{175} \mathrm{Lu}-\mathrm{DOTA}\left[\mathrm{Nle}^{15}\right] \mathrm{MG} 11$ and ${ }^{175} \mathrm{Lu}$-DOTA[Mox $\left.{ }^{15}\right]$ MG11 ( $\mathbf{a}$ ) from $100 \%$ binding to total displacement $(\mathrm{n}=3$ in triplicates). Data was fitted by nonlinear fit using GraphPad Prism.

\section{[FIGURE 4]}


Figure 4. Plasma stabilities of ${ }^{177} \mathrm{Lu}-\mathrm{DOTA}\left[\mathrm{Met}^{15}\right] \mathrm{MG} 11(\bullet),{ }^{177} \mathrm{Lu}-\mathrm{DOTA}\left[\mathrm{Nle}^{15}\right] \mathrm{MG} 11(\Delta)$ and ${ }^{177}$ Lu-DOTA[Mox $\left.{ }^{15}\right]$ MG11 ( ) over $24 \mathrm{~h}(\mathrm{n}=2-3)$. Data was fitted by nonlinear fit using GraphPad Prism. Error bars of individual time points are overlain by symbols used.

\section{CONCLUSIONS}

In summary, we report the employment of Mox as a stable substitute of the oxidationsensitive amino acid Met in radiolabeled tumour targeting peptides used as imaging probes or radioendotherapeutics. A systematic comparison of the physicochemical properties of minigastrin derivatives ${ }^{177} \mathrm{Lu}$-DOTA $\left[\mathbf{X}^{15}\right]$ MG11 $(\mathbf{X}=$ Met, Nle, Mox $)$ in vitro showed that the replacement of $\mathrm{Met}^{15}$ by either $\mathrm{Nle}^{15}$ or $\mathrm{Mox}^{15}$ does not impair the biological properties but enhances favourably their stability during radiolabeling procedures. Because Mox resembles more closely the steric and electronic properties of Met in comparison to reported Nle, its application in the development of radiolabeled peptides could be advantageous.

\section{ACKOWLEDGEMENT}

This work was supported by the Swiss National Science Foundation (grant 200021-157076 to T. L. M.). We thank Alain Blanc and Olga Gasser (PSI, Villigen, Switzerland) for technical support, and Andreas Ritler (ETH Zurich, Switzerland) for scientific discussions. The MZCRC1 cells were a kind gift of Prof. Dr. Alexander Knuth (Department of Oncology, University Hospital Zurich, Zurich, Switzerland).

\section{REFERENCES}

[1]C. L. Charron, J. L. Hickey, T. K. Nsiama, D. R. Cruickshank, W. L. Turnbull, L. G. Luyt, Molecular imaging probes derived from natural peptides, Nat. Prod. Rep., 2016, 33, 761, $10.1039 /$ C5NP00083A

[2]M. Fani, H. R. Maecke, Radiopharmaceutical development of radiolabelled peptides, Eur. J. Nucl. Med. Mol. Imaging, 2012, 39, 11, 10.1007/s00259-011-2001-z

[3]M. Schottelius, H.-J. Wester, Molecular imaging targeting peptide receptors, Methods, 2009, 48, 161, 10.1016/j.ymeth.2009.03.012

[4]W. A. P. Breeman, A. C. Fröberg, E. de Blois, A. van Gameren, M. Melis, M. de Jong, T. Maina, B. A. Nock, J. L. Erion, H. R. Mäcke, E. P. Krenning, Optimised labeling, preclinical and initial clinical aspects of CCK-2 receptor-targeting with 3 radiolabeled peptides, Nucl. Med. Biol., 2008, 35, 839, 10.1016/j.nucmedbio.2008.09.006

[5]R. T. Jensen, J. F. Battey, E. R. Spindel, R. V. Benya, International Union of Pharmacology. LXVIII. Mammalian Bombesin Receptors: Nomenclature, Distribution, Pharmacology, Signaling, and Functions in Normal and Disease States, Pharmacol. Rev., 2008, 60, 1, 10.1124/pr.107.07108 [6]M. Gotthardt, M. Fischer, I. Naeher, J. B. Holz, H. Jungclas, H.-W. Fritsch, M. Behe, B. Goke, K. Joseph, T. M. Behr, Use of the incretin hormone glucagon-like peptide-1 (GLP-1) for the detection of insulinomas: initial experimental results, Eur. J. Nucl. Med. Mol. Imaging, 2002, 29, 597, 10.1007/s00259-002-0761-1

[7]L. Aloj, M. Aurilio, V. Rinaldi, L. D'ambrosio, D. Tesauro, P. Peitl, T. Maina, R. Mansi, E. von Guggenberg, L. Joosten, J. Sosabowski, W. P. Breeman, E. De Blois, S. Koelewijn, M. Melis, B.

Waser, K. Beetschen, J. Reubi, M. de Jong, Comparison of the binding and internalization properties 
of 12 DOTA-coupled and 111In-labelled CCK2/gastrin receptor binding peptides: a collaborative project under COST Action BM0607, Eur. J. Nucl. Med. Mol. Imaging, 2011, 38, 1417, 10.1007/s00259-011-1816-y

[8]S. R. Vigna, A. S. Giraud, J. R. Reeve, Jr., J. H. Walsh, Biological activity of oxidized and reduced iodinated bombesins, Peptides, 1988, 9, 923, 10.1016/0196-9781(88)90142-8

[9]S. Good, M. Walter, B. Waser, X. Wang, J. Müller-Brand, M. Béhé, J.-C. Reubi, H. Maecke, Macrocyclic chelator-coupled gastrin-based radiopharmaceuticals for targeting of gastrin receptorexpressing tumours, Eur. J. Nucl. Med. Mol. Imaging, 2008, 35, 1868, 10.1007/s00259-008-0803-4 [10]I. E. Valverde, S. Vomstein, T. L. Mindt, Toward the Optimization of Bombesin-Based Radiotracers for Tumor Targeting, J. Med. Chem., 2016, 59, 3867, 10.1021/acs.jmedchem.6b00025 [11]M. Kirsi, Y. Cheng-Bin, V. Fagerholm, T. Ishizu, V.-V. Elomaa, J. Rajander, J. Jurttila, T. Saanijoki, T. Tolvanen, M. Tirri, E. Gourni, M. Behe, M. Gotthardt, J. C. Reubi, H. Macke, A. Roivainen, O. Solin, P. Nuutila, 64Cu- and 68Ga-labelled [Nle(14),Lys(40)(Ahx-NODAGA)NH2]exendin-4 for pancreatic beta cell imaging in rats, Mol. Imaging Biol., 2014, 16, 255, 10.1007/s11307013-0691-2

[12]T. M. Behr, N. Jenner, M. Béhé, C. Angerstein, S. Gratz, F. Raue, W. Becker, Radiolabeled Peptides for Targeting Cholecystokinin-B/Gastrin Receptor-Expressing Tumors, J. Nucl. Med, 1999, 40, 1029,

[13]A. Kaloudi, B. A. Nock, E. Lymperis, W. Sallegger, E. P. Krenning, M. de Jong, T. Maina, In vivo inhibition of neutral endopeptidase enhances the diagnostic potential of truncated gastrin 111Inradioligands, Nucl. Med. Biol., 2015, 42, 824, 10.1016/j.nucmedbio.2015.07.009

[14]E. Wuensch, L. Moroder, D. Gillessen, U. Soerensen, J. Bali, Biological and immunological properties of human gastrin I analogs, Hoppe-Seyler's Z. Physiol. Chem., 1982, 363, 665, [15]D. Gillessen, A. Trzeciak, R. K. M. Müller, R. O. Studer, Syntheses and biological activities of methoxinine-analogues of the C-terminal octapeptide of cholecystokinin-pancreozymin, Int. J. Pept. Protein Res., 1979, 13, 130, 10.1111/j.1399-3011.1979.tb01860.x

[16]L. Moroder, N. Budisa, Synthetic Biology of Protein Folding, ChemPhysChem, 2010, 11, 1181, 10.1002/cphc.201000035

[17]D. Besse, N. Budisa, W. Karnbrock, C. Minks, H. Musiol, S. Pegoraro, F. Siedler, E. Weyher, L. Moroder, Chalcogen-analogs of amino acids. Their use in x-ray crystallographic and folding studies of peptides and proteins, Biol. Chem., 1997, 378, 211, 10.1515/bchm.1997.378.3-4.211

[18]Peptides, Proc. Eur. Peptide Symp. Synthesis and biological activity of some peptides in which methionine has been replaced by methoxinine (Eds: H. Nesvadba), North-Holland, Vienna, Austria 1973.

[19]C. Wolschner, A. Giese, H. A. Kretzschmar, R. Huber, L. Moroder, N. Budisa, Design of anti- and pro-aggregation variants to assess the effects of methionine oxidation in human prion protein, 2009, 106, 7756, 10.1073/pnas.0902688106

[20]J. N. Crawley, R. L. Corwin, Biological actions of cholecystokinin, Peptides, 1994, 15, 731, 10.1016/0196-9781(94)90104-X

[21]G. J. Dockray, Topical Review, J. Physiol., 1999, 518, 315, 10.1111/j.1469-7793.1999.0315p.x [22]R. A. Gregory, H. J. Tracy, Isolation of two minigastrins from Zollinger-Ellison tumour tissue, Gut, 1974, 15, 683, 10.1136/gut.15.9.683

[23]J. C. Reubi, B. Waser, Unexpected high incidence of cholecystokinin-B/gastrin receptors in human medullary thyroid carcinomas, Int. J. Cancer, 1996, 67, 644, 10.1002/(SICI)10970215(19960904)67:5<644::AID-IJC9>3.0.CO;2-U

[24]P. Laverman, L. Joosten, A. Eek, S. Roosenburg, P. Peitl, T. Maina, H. Mäcke, L. Aloj, E. von Guggenberg, J. Sosabowski, M. de Jong, J.-C. Reubi, W. G. Oyen, O. Boerman, Comparative biodistribution of $12111 \mathrm{In}$-labelled gastrin/CCK2 receptor-targeting peptides, Eur. J. Nucl. Med. Mol. Imaging, 2011, 38, 1410, 10.1007/s00259-011-1806-0

[25]M. Ocak, A. Helbok, C. Rangger, P. Peitl, B. Nock, G. Morelli, A. Eek, J. Sosabowski, W. P. Breeman, J. Reubi, C. Decristoforo, Comparison of biological stability and metabolism of CCK2 receptor targeting peptides, a collaborative project under COST BM0607, Eur. J. Nucl. Med. Mol. Imaging, 2011, 38, 1426, 10.1007/s00259-011-1818-9

[26]A. Kaloudi, B. A. Nock, E. Lymperis, E. P. Krenning, M. de Jong, T. Maina, Improving the In Vivo Profile of Minigastrin Radiotracers: A Comparative Study Involving the Neutral Endopeptidase Inhibitor Phosphoramidon, Cancer Biother.Radiopharm., 2016, 31, 20, 10.1089/cbr.2015.1935 
[27]S. Roosenburg, P. Laverman, L. Joosten, A. Eek, W. J. G. Oyen, M. de Jong, F. P. J. T. Rutjes, F. L. van Delft, O. C. Boerman, Stabilized 111In-Labeled sCCK8 Analogues for Targeting CCK2Receptor Positive Tumors: Synthesis and Evaluation, 2010, 21, 663, 10.1021/bc900465y [28]A. Helbok, C. Decristoforo, M. Behe, C. Rangger, E. v. Guggenberg, Preclinical Evaluation of In111 and Ga-68 Labelled Minigastrin Analogues for CCK-2 Receptor Imaging, 2009, 2, 304, [29]M. Behe, R. Schibli, (P. S. I. Villigen), WO2015067473 A1, 2015

[30]E. Kaiser, R. L. Colescott, C. D. Bossinger, P. I. Cook, Color test for detection of free terminal amino groups in the solid-phase synthesis of peptides, Anal. Biochem. , 1970, 34, 595, 10.1016/00032697(70)90146-6

[31]A. Mascarin, I. E. Valverde, S. Vomstein, T. L. Mindt, 1,2,3-Triazole Stabilized NeurotensinBased Radiopeptidomimetics for Improved Tumor Targeting, Bioconjugate Chem., 2015, 26, 2143 , 10.1021/acs.bioconjchem.5b00444

[32]I. E. Valverde, A. Bauman, C. A. Kluba, S. Vomstein, M. A. Walter, T. L. Mindt, 1,2,3-Triazoles as Amide Bond Mimics: Triazole Scan Yields Protease-Resistant Peptidomimetics for Tumor

Targeting, Angew. Chem., Int. Ed. , 2013, 52, 8957, 10.1002/anie.201303108 
Table 1. Structures, yields, and analytical data of the investigated peptide conjugates.

\begin{tabular}{|c|c|c|c|c|c|}
\hline Compound & Structure & $\begin{array}{l}\text { Yield } \\
{[\%]^{\mathrm{a}}}\end{array}$ & $\begin{array}{c}\text { Purity } \\
{[\%]^{\mathbf{b}}}\end{array}$ & $\begin{array}{c}\mathbf{m} / \mathbf{z} \\
\text { found }^{\mathbf{c}}\end{array}$ & $\underset{[\mathrm{g} / \mathrm{mol}]}{\text { M }_{\mathrm{w}} \text { calcd. }}$ \\
\hline $\begin{array}{l}\text { DOTA }\left[\mathrm{Met}^{15}\right] \\
\text { MG11 }\end{array}$ & $\begin{array}{l}\text { DOTA-DGlu-Ala-Tyr- } \\
\text { Gly-Trp-Met-Asp-Phe- } \\
\qquad \mathrm{NH}_{2}\end{array}$ & 52 & $>99 \%$ & $\begin{array}{c}1403.5926 \\
{[\mathrm{M}+\mathrm{H}]^{+}}\end{array}$ & $\begin{array}{c}1402.5864 \\
\left(\mathrm{C}_{64} \mathrm{H}_{86} \mathrm{~N}_{14} \mathrm{O}_{20} \mathrm{~S}\right)\end{array}$ \\
\hline $\begin{array}{l}\text { DOTA }\left[\mathrm{Nle}^{15}\right] \\
\text { MG11 }\end{array}$ & $\begin{array}{l}\text { DOTA-DGlu-Ala-Tyr- } \\
\text { Gly-Trp-Nle-Asp-Phe- } \\
\qquad \mathrm{NH}_{2}\end{array}$ & 71 & $>99 \%$ & $\begin{array}{c}1385.6372 \\
{[\mathrm{M}+\mathrm{H}]^{+}}\end{array}$ & $\begin{array}{c}1384.6299 \\
\left(\mathrm{C}_{65} \mathrm{H}_{88} \mathrm{~N}_{14} \mathrm{O}_{20}\right)\end{array}$ \\
\hline $\begin{array}{l}\text { DOTA }\left[\operatorname{Mox}^{15}\right] \\
\text { MG11 }\end{array}$ & $\begin{array}{l}\text { DOTA-DGlu-Ala-Tyr- } \\
\text { Gly-Trp-Mox-Asp-Phe- } \\
\mathrm{NH}_{2}\end{array}$ & 76 & $>99 \%$ & $\begin{array}{c}694.3119 \\
{[\mathrm{M}+2 \mathrm{H}]^{2+}}\end{array}$ & $\begin{array}{c}1386.6092 \\
\left(\mathrm{C}_{64} \mathrm{H}_{86} \mathrm{~N}_{14} \mathrm{O}_{21}\right)\end{array}$ \\
\hline
\end{tabular}

Table 2: Physicochemical properties of (radio)metal labeled peptides.

\begin{tabular}{|c|c|c|c|c|c|}
\hline Compound & $\begin{array}{c}\mathrm{IC}_{50} \\
{[\mathrm{nM}]^{\mathrm{a}, \mathrm{b}, \mathrm{c}}}\end{array}$ & $\begin{array}{c}\text { Internalization } \\
{[\%]^{\mathrm{b}, \mathrm{d}, \mathrm{e}}}\end{array}$ & $\begin{array}{c}\text { Externalization } \\
{[\%]^{b, d, f}}\end{array}$ & $\begin{array}{l}\text { Half- } \\
\text { life } \\
{[\mathrm{h}]^{\mathrm{d}, \mathrm{g}}}\end{array}$ & $\log D^{b, d, h}$ \\
\hline $\begin{array}{l}\text { Lu-DOTA } \\
{\left[\mathrm{Met}^{15}\right] \mathrm{MG} 11}\end{array}$ & $25.2 \pm 5.8$ & $24.5 \pm 9.2$ & $43.4 \pm 3.3$ & 2.4 & $-3.3 \pm 0.2$ \\
\hline $\begin{array}{l}\text { Lu-DOTA } \\
{\left[\mathrm{Nle}^{15}\right] \mathrm{MG} 11}\end{array}$ & $17.5 \pm 5.0$ & $27.8 \pm 6.7$ & $43.3 \pm 1.6$ & 1.7 & $-3.5 \pm 0.2$ \\
\hline $\begin{array}{l}\text { Lu-DOTA } \\
{\left[\operatorname{Mox}^{15}\right] \mathrm{MG} 11}\end{array}$ & $19.9 \pm 2.9$ & $20.1 \pm 2.8$ & $48.2 \pm 0.3$ & 1.9 & $-3.6 \pm 0.6$ \\
\hline \multicolumn{6}{|c|}{$\begin{array}{l}{ }^{\mathrm{a}} \mathrm{Lu}={ }^{175} \mathrm{Lu} ;{ }^{\mathrm{b}} \text { data is presented as mean values } \pm \text { standard deviations ( } \mathrm{n}=3 \text { in triplicates); } \\
\text { determined by competition experiments; }{ }^{\mathrm{d}} \mathrm{Lu}={ }^{\mathrm{c}}{ }^{177} \mathrm{Lu} ;{ }^{\mathrm{e}} \text { specific cell uptake of total applied } \\
\text { radioactivity after } 4 \text { hours as mean values } \pm \text { standard deviations }(\mathrm{n}=3-4 \text { in triplicates); } \\
\text { externalized fraction of radioactivity after } 4 \mathrm{~h} \text { as mean values } \pm \text { standard deviations }(\mathrm{n}=1-2 \text { in } \\
\text { triplicates); }{ }^{\mathrm{g}} \text { determined in human blood plasma, calculated with by GraphPad Prism using } \\
\text { the equation } \mathrm{A}=\mathrm{A}_{0} * \mathrm{e}^{-\mathrm{kt}}(\mathrm{n}=2) ;{ }^{\mathrm{h}} \text { determined by the shake flask method as mean values } \pm \\
\text { standard deviations }(\mathrm{n}=3) .\end{array}$} \\
\hline
\end{tabular}


Figure 2. Internalization of $177 \mathrm{Lu}$-radiolabeled peptide conjugates into MZ-CRC1 cells. Blocking experiments were performed in the presence of 5000-fold molar excess of Minigastrin; results are given as mean values \pm standard deviations ( $n=3-4$ in triplicates); detailed information can be found in the Supporting Information.

$78 \times 50 \mathrm{~mm}(300 \times 300$ DPI $)$ 


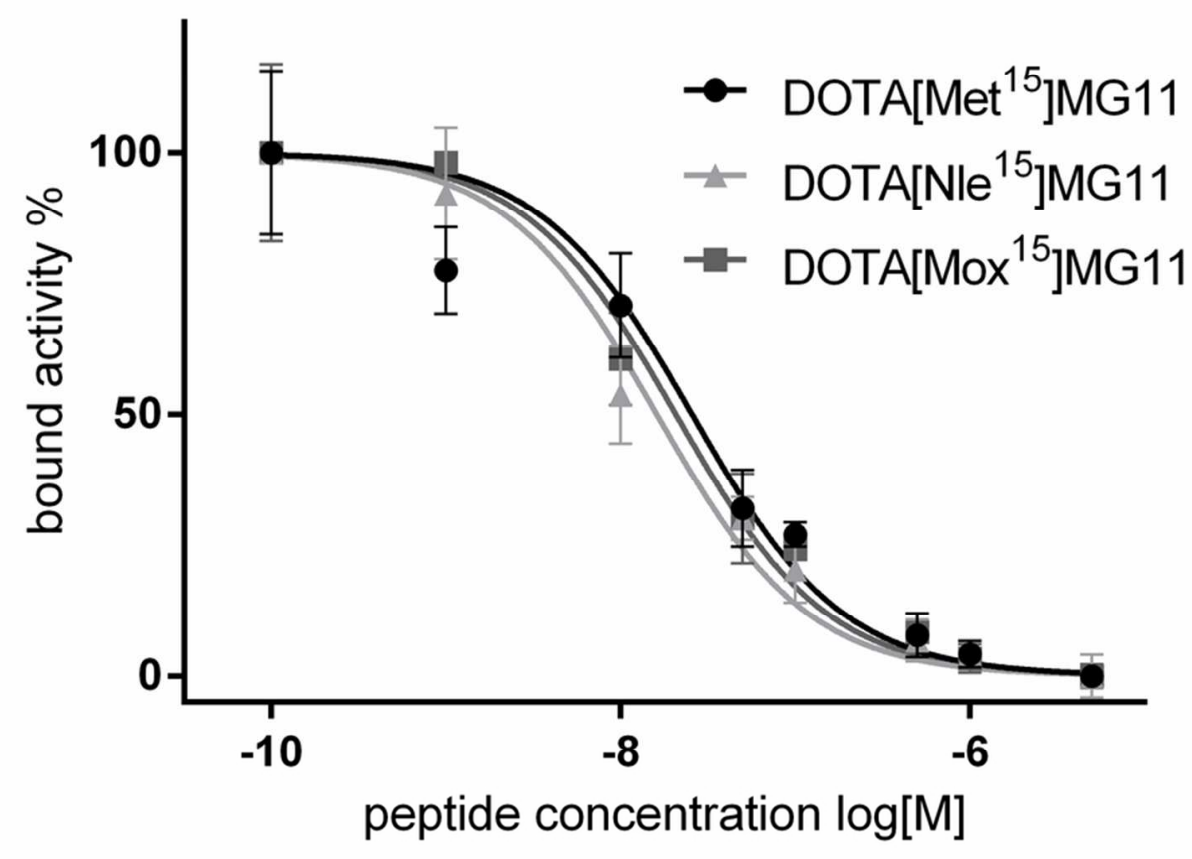

Figure 3. Receptor bound fraction of reference compound 177Lu-DOTA-PP-F11N [[29]]with increasing concentrations of 175Lu-DOTA[Met15]MG11 (•), 175Lu-DOTA[Nle15]MG11 ( ) and 175LuDOTA[Mox15]MG11 ( ) from $100 \%$ binding to total displacement ( $n=3$ in triplicates). Data was fitted by nonlinear fit using GraphPad Prism.

$82 \times 59 \mathrm{~mm}(300 \times 300 \mathrm{DPI})$ 


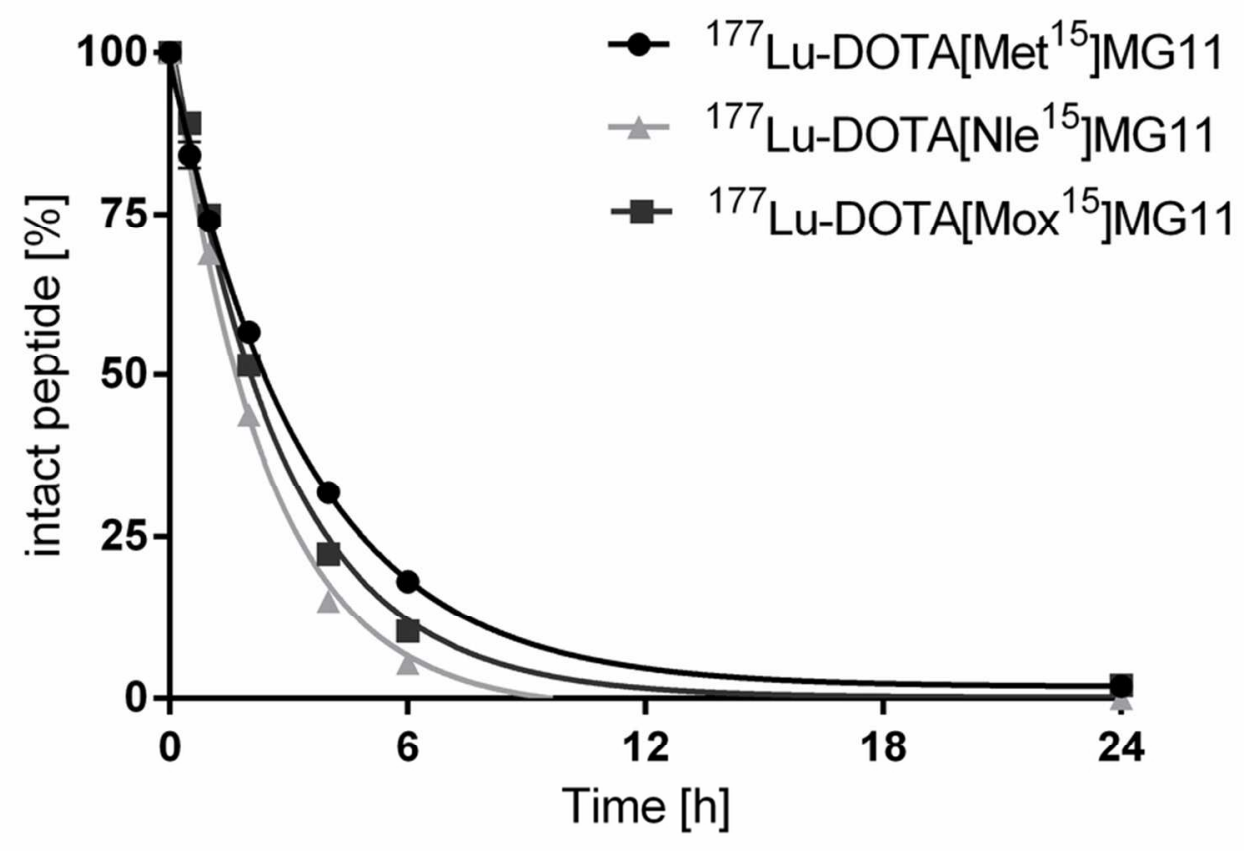

Figure 4. Plasma stabilities of 177Lu-DOTA[Met15]MG11 (•), 177Lu-DOTA[Nle15]MG11 ( ) and 177LuDOTA[Mox15]MG11 ( ) over $24 \mathrm{~h}(\mathrm{n}=2-3)$. Data was fitted by nonlinear fit using GraphPad Prism. Error bars of individual time points are overlain by symbols used.

$80 \times 55 \mathrm{~mm}(300 \times 300 \mathrm{DPI})$ 
Methoxinine - An Alternative Stable Amino Acid Substitute for ${ }_{3}^{1}$ Oxidation-Sensitive Methionine in Radiolabeled Peptide Conjugates 4

${ }_{6}^{5}$ Nathalie M. Grob, Martin Behe, ${ }_{9}^{8}$ Elisabeth von Guggenberg, Roger ${ }_{11}^{1}$ Schibli, Thomas L. Mindt*

Tideplacement of the amino acid Met Thy Nle $\left(\mathrm{X}=\mathrm{CH}_{2}\right)$ and/or Mox $(\mathrm{X}=\mathrm{O})$ in 2ithe sequence of minigastrin analogs 21 ${ }_{2}^{2}$ provides tumour-targeting peptide ${ }_{2450}^{24}$ jugates which exhibit maintained ${ }_{2}^{2}$ biological activity and are stable 280wards oxidative side reactions 30 .
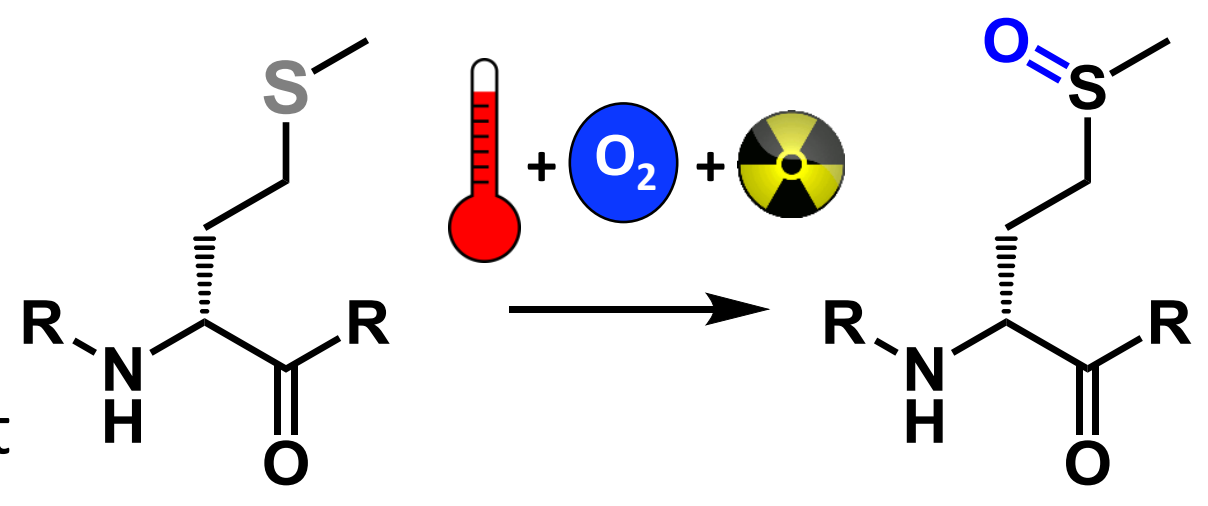

side products

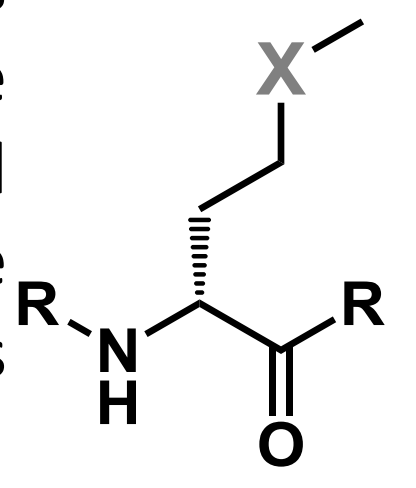

